\title{
Evaluation of Genetic Variability for Quantitative Characters in Moth Bean [Vigna aconitifolia (Jacq) Marechal] Local Germplasm
}

\author{
S.N. Kohakade ${ }^{1}$, V.V. Bhavsar ${ }^{1 *}$ and V.Y. Pawar $^{2}$ \\ ${ }^{1}$ Department of Botany, College of Agriculture, Dhule (MS), India \\ ${ }^{2}$ Bajra Research Scheme, College of Agriculture, Dhule (MS), India \\ *Corresponding author
}

\section{A B S T R A C T}

\begin{tabular}{|c|}
\hline Keywords \\
\hline $\begin{array}{l}\text { Moth bean, Genetic } \\
\text { Variability, } \\
\text { Heritability, } \\
\text { Genetic Advance. }\end{array}$ \\
\hline Article Info \\
\hline $\begin{array}{l}\text { Accepted: } \\
28 \text { August } 2017 \\
\text { Available Online: } \\
\text { 10 September } 2017\end{array}$ \\
\hline
\end{tabular}

\section{Keywords}

Moth bean, Genetic

Variability,

Heritability,

Genetic Advance.

10 September 2017
A study was undertaken to determine the extent of genetic variability for seed yield and ten other quantitative characters in 44 genotypes of moth bean. The analysis of variance revealed significant differences among genotypes for all the characters. High genotypic coefficient and phenotypic coefficient of variation was recorded for seed yield per plant followed by length of main axis, number of pods per plant, number of cluster per plant, days to $50 \%$ flowering, number of pods per cluster and number of seeds per pod. High heritability was recorded for days to $50 \%$ flowering, length of main axis, days to maturity, number of pods per plant, seed yield per plant, number of primary branches, number of cluster per plant, 100 seed weight, number of pods per cluster and number of seeds per pod. High heritability (broad) coupled with high genetic advance as per cent of mean was observed for length of main axis, number of pods per plant, days to 50 per cent flowering, days to maturity, number of cluster per plant and seed yield per plant. Thus, these traits are predominantly under the control of additive gene action and hence characters can be improved by selection.

\section{Introduction}

Moth bean [Vigna aconitifolia (Jacq) Marechal] belongs to family: Leguminosae /Fabaceae, sub family: Papilionaceae. It is a self-pollinated diploid $(2 \mathrm{n}=22)$ crop. Popularly, it is also known as 'Mat', 'Matki' and 'Moth bean' in different regions. Plant is an annual with spreading prostrate habit forming a mat like cover on soil, hence its name as a mat or moth bean. Canopy of moth bean covers surface area which conserves moisture and protects the soil from erosion. Moth bean is mainly used as "Dal" and some other preparations. Green pods are used as vegetables. It can also be used as green fodder for animals.
It is an important crop of dry and semi-arid areas of India and some countries of Asia. Among Kharif pulses, it has maximum capacity to resist drought condition. It is an excellent source of high quality protein $(23.6 \%)$ in the diet of low income group in developing countries. Moth bean is cultivated for food as well as forage. In extremely low rainfall areas, it is grown alone as pure crop, while, in areas receiving adequate rains it may be grown as intercrop with pearl millet, sorghum, cotton, green gram or some other fodder grasses. India has major area under moth bean cultivated in world. It is also grown in Pakistan, Shrilanka, China, and 
United States of America (USA). In India moth bean is mainly grown in Rajasthan which contribute about $75 \%$ of total area and production of the country. Other important states for cultivation of moth bean are Maharashtra, Gujarat, Jammu \& Kashmir and Punjab.

Information on genetic variability, heritability and genetic advance is most essential for formulating effective selection schemes in any crop improvement programme. A very limited work of this kind has been previously done on moth bean. Therefore, the present investigations were undertaken to determine genetic variability, heritability and genetic advance in moth bean.

\section{Materials and Methods}

The experimental materials consisting forty four germplasm of moth bean collected from Solapur, Ahmednagar, Pune, Dhule and Nandurbar districts of Maharashtra (Table 2). The experiment was laid out in RBD with three replications at Department of Botany, College of Agriculture, Dhule (M.S.). By adopting a spacing of $30 \mathrm{~cm}$ between rows and $10 \mathrm{~cm}$ between plants respectively, at recommended package of practices were followed to raise good and healthy crop stand. Data were collected on eleven yield and yield contributing characters viz., days to $50 \%$ flowering, days to maturity, length of main axis, number of primary branches, number of cluster per plant, number of pods per cluster, number of pods per plant, pod length, seeds per pod, 100 seed weight, seed yield per plant.

The mean of five plants was subjected to statistical analysis. The data for different characters were statistically analyzed for significance by using analysis of variance technique described by Panse and Sukhatme (1985).The adapted design was Randomized Block Design (RBD) with three replications. The significance of mean sum of square for each character was tested against the corresponding error degrees of freedom using "F" Test (Fisher and Yates, 1967).The components of variances were used to estimate genetic parameters like phenotypic and genotypic coefficient of variation (PCV and GCV) as per the formula given by Burton and De Vane (1953).Heritability in broad sense was calculated according to the formula given by Allard (1960) and expressed in percentage. Genetic advance was estimated by using Burton (1955). Statistical analysis was done by using WINDOSTAT program.

\section{Results and Discussion}

Analysis of variance revealed significant differences among genotypes for all the characters. Studies of genetic variability exhibited high phenotypic and genotypic coefficients of variation, heritability and genetic advance as percent of mean for the traits viz., Seed yield per plant, length of main axis, Number of pods per plant, number of clusters per plant, number of primary branches, days to maturity and number of pods per cluster indicating simple selection can be practiced for improvement of these characters (Table 1). It shows that the presence of variability and choice of material is appropriate.

Improvement of economic characters like yield through selection is conditioned by the nature and magnitude of variability existing in such populations. However, the phenotypic expression of complex character like yield is a combination of genotype, environment and their interaction. This indicates the need for partition of overall variability into heritable and non-heritable components with the help of appropriate statistical techniques.

Possibility of achieving improvement in any crop plants depends largely on the magnitude of genetic variability. Phenotypic variability expressed by a genotype or a group of 
genotypes in any species can be partitioned into genotypic and environmental components. The genotypic component being the heritable part of the total variability, its magnitude for yield and its component characters influence the selection strategies to be adopted by the breeders.
Coefficients of variation studies indicated that the estimates of PCV were slightly higher than the corresponding GCV estimates for all the characters, indicating that the characters were less influenced by the environment. Therefore, selection for the improvement of these traits.

Table.1 Analysis of variance for different characters in moth bean

\begin{tabular}{|c|l|c|c|c|}
\hline \multirow{2}{*}{$\begin{array}{c}\text { Sr. } \\
\text { No }\end{array}$} & \multicolumn{1}{|c|}{ Characters } & \multicolumn{2}{l|}{ Mean sum of square } \\
\cline { 2 - 4 } & Replication & Genotype & Error \\
\hline 1 & Days to 50\% flowering & 1.96 & $1464.9^{* *}$ & 2.82 \\
\hline 2 & Days to maturity & 2.550 & $1273.26^{* *}$ & 6.67 \\
\hline 3 & Length of main axis (cm) & 9.490 & $9951.60^{* *}$ & 35.49 \\
\hline 4 & Number of primary branches & 0.12 & $7.67 * *$ & 0.19 \\
\hline 5 & Number of cluster per plant & 0.034 & $419.32^{* *}$ & 11.29 \\
\hline 6 & Number of pods per cluster & 0.037 & $0.52^{* *}$ & 0.02 \\
\hline 7 & Number of pods per plant & 1.330 & $3303.82^{* *}$ & 45.99 \\
\hline 8 & Pod length (cm) & 0.011 & $0.108^{* *}$ & 0.032 \\
\hline 9 & Number of seeds per pod & 0.062 & $2.988^{* *}$ & 0.139 \\
\hline 10 & 100 seed weight (g) & 0.011 & $0.290^{* *}$ & 0.010 \\
\hline 11 & Grain yield per plant (g) & 0.016 & $65.177^{* *}$ & 0.957 \\
\hline
\end{tabular}

$*, * *$ Indicates significance at $5 \%$ and $1 \%$ level, respectively.

Table.2 List of moth bean genotypes with origin

\begin{tabular}{|l|l|l|l|l|l|}
\hline Sr. No. & Genotypes & Source & Sr. No. & Genotypes & Source \\
\hline 1 & MBS-0835 & Solapur & 23 & DHMB-11 & Dhule \\
\hline 2 & MBS0845 & Solapur & 24 & DHMB-12 & Baragaonnandur,Rahuri (Ahmednagar) \\
\hline 3 & MBS-0803 & Solapur & 25 & DHMB-13 & Baragaonnandur,Rahuri (Ahmednagar) \\
\hline 4 & MBS-0847 & Solapur & 26 & DHMB-14 & Dahiwade, (Satara) \\
\hline 5 & MBS-0828 & Solapur & 27 & DHMB-15 & Shevgaon, (Ahmednagar) \\
\hline 6 & MBS-O855 & Solapur & 28 & DHMB-16 & Shirur, (Pune) \\
\hline 7 & MBS-0853-2 & Solapur & 29 & DHMB-17 & Karjat, (Ahmednagar) \\
\hline 8 & MBS-0853-1 & Solapur & 30 & DHMB-18 & Shrigonda, (Ahmednagar) \\
\hline 9 & MBS-0814 & Solapur & 31 & DHMB-19 & Pathardi (Ahmednagar) \\
\hline 10 & MBS-0605 & Solapur & 32 & DHMB-20 & Akole, (Ahmednagar) \\
\hline 11 & MBS-0851 & Solapur & 33 & DHMB-21 & Pathardi (Ahmednagar) \\
\hline 12 & MBS-27(C) & Solapur & 34 & DHMB-22 & Man (Satara) \\
\hline 13 & DHMB-1 & Rahuri (Ahmednagar) & 35 & DHMB-23 & Baramati, (Pune) \\
\hline 14 & DHMB-2 & Kada (Beed) & 36 & DHMB-24 & Karjat, (Ahmednagar) \\
\hline 15 & DHMB-3 & Nandurbar & 37 & DHMB-25 & Parner, (Ahmednagar) \\
\hline 16 & DHMB-4 & Akole (Ahmednagar) & 38 & DHMB-26 & Dhule \\
\hline 17 & DHMB-5 & Man (Satara) & 39 & DHMB-27 & Dhule \\
\hline 18 & DHMB-6 & Sindakheda (Dhule) & 40 & DHMB-28 & Dhule \\
\hline 19 & DHMB-7 & Nandurbar & 41 & DHMB-29 & Shrigonda, (Ahmednagar) \\
\hline 20 & DHMB-8 & Sindakheda (Dhule) & 42 & DHMB-30 & Shewgaon, (Ahmednagar) \\
\hline 21 & DHMB-9 & Rohane, Sindakheda (Dhule) & 43 & DHMB-31 & Karjat, (Ahmednagar) \\
\hline 22 & DHMB-10 & Wambori,Rahuri (Ahmednagar) & 44 & DHMB-32 & Ambegaon (Pune) \\
\hline
\end{tabular}


Table.3 Parameters of genetic variability for different characters in Moth bean

\begin{tabular}{|c|c|c|c|c|c|c|c|c|c|c|c|}
\hline $\begin{array}{l}\text { Sr. } \\
\text { No }\end{array}$ & Characters & $\begin{array}{c}\text { General } \\
\text { Mean }\end{array}$ & $\sigma^{2} g$ & $\sigma^{2} p$ & $\sigma^{2} \mathrm{e}$ & $\begin{array}{c}\text { GCV } \\
(\%)\end{array}$ & $\begin{array}{c}\text { PCV } \\
(\%)\end{array}$ & $\begin{array}{c}\text { ECV } \\
(\%)\end{array}$ & $\begin{array}{c}\mathbf{h}^{2} \\
(\mathrm{BS} \\
\%)\end{array}$ & GA & $\begin{array}{c}\text { GA as } \\
\% \text { of } \\
\text { mean }\end{array}$ \\
\hline 1 & Days to $50 \%$ flowering & 84.93 & 487.36 & 490.18 & 2.82 & 25.99 & 26.07 & 1.98 & 99.42 & 45.35 & 53.39 \\
\hline 2 & Days to maturity & 135.09 & 422.20 & 428.87 & 6.67 & 15.21 & 15.33 & 1.91 & 98.44 & 41.99 & 31.09 \\
\hline 3 & Length of main axis $(\mathrm{cm})$ & 107.44 & 3305.37 & 3340.85 & 35.49 & 53.51 & 53.80 & 5.54 & 98.94 & 117.8 & 109.64 \\
\hline 4 & No. of primary branches & 5.01 & 2.49 & 2.68 & 0.19 & 31.65 & 32.86 & 8.81 & 92.81 & 3.13 & 62.82 \\
\hline 5 & No. of cluster / plant & 35.09 & 136.01 & 147.30 & 11.29 & 33.23 & 34.58 & 9.57 & 92.33 & 23.09 & 65.77 \\
\hline 6 & No. of pods / cluster & 1.79 & 0.1644 & 0.18 & 0.02 & 22.55 & 24.02 & 8.28 & 88.11 & 0.78 & 43.60 \\
\hline 7 & No. of pods / plant & 66.05 & 1085.94 & 1131.94 & 45.99 & 49.90 & 50.94 & 10.27 & 95.94 & 66.49 & 100.67 \\
\hline 8 & Pod length $(\mathrm{cm})$ & 3.37 & 0.02 & 0.05 & 0.031 & 4.74 & 7.10 & 5.28 & 44.54 & 0.22 & 6.51 \\
\hline 9 & No. of seeds /pod & 5.67 & 0.94 & 1.08 & 0.13 & 17.18 & 18.40 & 6.59 & 87.16 & 1.87 & 33.05 \\
\hline 10 & 100 seed weight $(\mathrm{g})$ & 2.32 & 0.09 & 0.10 & 0.01 & 13.20 & 13.89 & 4.34 & 90.25 & 0.598 & 25.82 \\
\hline 11 & Seed yield /plant (g) & 6.94 & 21.41 & 22.36 & 0.957 & 66.60 & 68.07 & 14.08 & 95.72 & 9.325 & 134.23 \\
\hline
\end{tabular}


The difference between GCV and PCV values was more for number of pods per plant, number of cluster per plant, length of main axis indicating that selection based on phenotypic observation may not be very effective for these traits (Table 3). The GCV and PCV were high for seed yield per plant, number of pods per plant, length of main axis, number of cluster per plant, number of primary branches showing greater scope for selection for improvement of these characters. Similar results obtained to Tikka et al., (1973); Jindal and Vir (1983); Natrajan et al., (1988); Bhavsar and Birari (1989); Garg et al., (2003); Yogeesh et al., (2012) in moth bean.

High heritability coupled with high genetic advance reveals the presence of lesser environmental influence and prevalence of additive gene action in their expression (Panse, 1957). Lower values of genetic advance indicate the prevalence of narrow range of variability, high $\mathrm{G} X \mathrm{E}$ interaction (non-additive gene action). In the present investigation high heritability coupled with high genetic advance as per cent of mean was observed for length of main axis, number of pods per plant, days to 50 per cent flowering, days to maturity, number of cluster per plant and seed yield per plant suggesting that these characters are govern by additive genes and phenotypic selection for these characters may be effective. Previously similar results were reported by Tikka et al., (1973); Tikka et al., (1977); Jat (1984); Bhavsar and Birari (1989); Garg et al., (2003); Sihag et al., (2004) and Yogeesh et al., (2016). High heritability with low genetic advance was observed for number of pods per cluster, 100 seed weight, pod length and number of seeds per pod. This indicates non-additive gene action and selection in early genotypes for such traits may not be effective. The findings of present study coinside with those obtained by Bhavsar and Birari (1989) for pod length and number of seeds per pod.
Genotypic coefficient of variation (GCV) along with heritable estimates would provide a better picture of the amount of genetic advance to be expected by phenotypic selection (Burton, 1953). It is suggested that genetic gain should be considered in conjuction with heritability estimates (Johnson et al., 1955).Heritability estimates along with genetic advance are niomally more helpful in predicting the gain under selection than heritability estimates alone (Table 3 ).

In conclusion, the material chosen differed in their genotypic make up as evidenced by the significant differences among them in respect of all the quantitative characters studied. Phenotypic coefficients of variations estimate was slightly higher than the genotypic coefficients of variation for all the trait, indicating low environmental influence on the expression of all the traits.

\section{References}

Allard, R.W., 1960. Principles of plant breeding. John Willey and Sons Inc. New York.pp485

Bhavsar, V. V., and Birari, S. P. 1989. Variability, correlation and path analysis in moth bean. J. Maharashtra agric. Univ., 14(2):148-150.

Burton, G.W., 1953.Quantitative inheritance in grasses.Proceeding on $6^{\text {th }}$ International Grass Land Congress J. 1:277-283.

Burton, G.W., and De Vane, E.H.1952.Estimating heritability in tall Fescue (Festuca arundinacea) from replicated clonal material. Agronomy J., 45:478-481.

Fisher, R.A., and Yates. 1967. Statistical Tables for Biological Agricultural and Medical Research Oliver and Boyd, Edington.

Garg, D.K., Kakani, R. K., Sharma, R. C. and Gupta, P. C. 2003. Genetic variability and character association in moth bean 
under hyper Arid Region, Agriculture Research Station Bikaner. Advances Arid Legumes Res., pp. 93-97.

Jat, P. M., 1984. Association analysis and genetic divergence in moth bean. M. Sc. (Agri.) Thesis, Univ. of Udaipur, Rajasthan.

Jindal, S. K., and Vir, S. 1983. Studies on variability and character association in moth bean. Annals Arid Zone, 22: 221226.

Johnson, H.W., Robinson, H.F. and Comstock, R.E. 1955. Estimates of genetic and environmental variability in soybean. Agron. J., 47: 314-318.

Natarajan, C., Thiyagarajan, K. and Rathnaswamy, R. 1988. Association and genetic diversity studies in green gram. Madras Agric. J. 75 (7-8):238245.

Panse, V.G., and Sukhatme, P.V. 1985. Statistical Methods for Agricultural Workers. Indian Council of Agricultural Research, New Delhi.

Sihag, S. K., Khatri, R. S. and Joshi. U. N. 2004. Genetic variability and heritability for grain yield and its component in moth bean. Annals Biology, 20(2):219-222.

Singh, R. K., and Choudhary. B. D. 1977. Variance and covariance analysis. "Biometrical methods in quantitative genetic analysis." Kalyani publication, New Delhi, pp.39-68.

Tikka S. B., Asawa, B. M. and Kumar, S. 1977. Correlated response to selection in moth bean. Gujarat Agric.Univ. Res. J., 3:142-144.

Tikka, S. B., Yadavendra J. P. and Boradia P. C. 1973. Variation in moth bean. Rajasthan Agric. Sci., 4:50-55

Yogeesh, L. N., Viswanatha, K. P. and Ganagaprasad, B. A. 2012. Genetic variability studies in moth bean germplasm for seed yield and its attributing characters. Electronic Journal Plant Breeding, 3(1):671-675.

Yogeesh, L. N., Viswanatha, K. P., Madhusudhan, R., and Gangaprasad. 2016 Morphological Diversity and Genetic Variability in Moth bean. Internal. J. Sci, Environ. And technol., 5(4): 1912-1924.

\section{How to cite this article:}

Kohakade, S.N., V.V. Bhavsar and Pawar, V.Y. 2017. Evaluation of Genetic Variability for Quantitative Characters in Moth Bean [Vigna aconitifolia (Jacq) Marechal] Local Germplasm. Int.J.Curr.Microbiol.App.Sci. 6(9): 3163-3168. doi: https://doi.org/10.20546/ijcmas.2017.609.390 